\title{
Assessing a population-based approach to the management of respiratory disease
}

\author{
C Hampson ${ }^{1}$, O Latycheva ${ }^{1 *}$, MM Vine ${ }^{2}$, SJ Elliott ${ }^{2}$, M Haynes $^{1}$ \\ From Canadian Society of Allergy and Clinical Immunology Annual Scientific Meeting 2009 \\ Halifax, Canada. 22-25 October 2009
}

The prevalence of respiratory disease (asthma, allergies and COPD) has increased dramatically in the last 25 years, with a heavy economic and social burden. Provision of information is recognized as a means to improve patient knowledge and self-management skills, and can overall result in improved disease management and quality of life. The Partnership in Lung Age Testing and Education (PLATE) Programme was a one-year demonstration project designed to investigate the effectiveness of a population-based approach to the management of respiratory disease. The PLATE objectives were: to improve patient education and disease management skills; increase public awareness about respiratory disease; and promote a healthy lifestyle. During phase one, 13 Airways Clinics were established in Toronto and Hamilton at various community settings (e.g. pharmacies, shopping malls, libraries), providing community residents with respiratory health education, which aimed to improve the implementation of best practices for chronic disease management through clinical assessments, peak flow testing, and follow-up with regular health care providers. Project participants were categorized into three groups: 1) with physician-diagnosed asthma (61\%); 2) with physician-diagnosed COPD (11\%); and 3) with respiratory symptoms, but without a diagnosis and/or long-time smokers (28\%). More than half $(60 \%)$ of the participants were female; over $75 \%$ were over the age of 40 years. Participants were provided with an educational kit to encourage ongoing education for management of their chronic disease. Phase two is currently under-way and includes a community outreach component, in addition to a follow-up survey to examine changes in the levels of knowledge gained from phase one. Despite the small sample size (87 participants), findings indicate that the highest level of interest

\footnotetext{
* Correspondence: oxana@asthma.ca

${ }^{1}$ The Asthma Society of Canada, Canada
}

came from high-needs communities, and that pharmacies are the most appropriate setting within which to host clinics, while shopping malls are best for information displays. More research is needed to confirm these findings.

\section{Author details \\ ${ }^{1}$ The Asthma Society of Canada, Canada . ${ }^{2}$ School of Geography and Earth Sciences, McMaster University, Canada.}

Published: 12 May 2010

doi:10.1186/1710-1492-6-S1-P11

Cite this article as: Hampson et al:: Assessing a population-based approach to the management of respiratory disease. Allergy, Asthma \& Clinical Immunology 2010 6(Suppl 1):P11.
Submit your next manuscript to BioMed Central and take full advantage of:

- Convenient online submission

- Thorough peer review

- No space constraints or color figure charges

- Immediate publication on acceptance

- Inclusion in PubMed, CAS, Scopus and Google Scholar

- Research which is freely available for redistribution

Submit your manuscript at www.biomedcentral.com/submit
C Biomed Central 